\title{
Allometric equations for maximum filtration rate in blue mussels Mytilus edulis and importance of condition index
}

\author{
Hans Ulrik Riisgård · Poul S. Larsen • \\ Daniel Pleissner
}

Received: 29 October 2013/Revised: 19 December 2013/Accepted: 21 December 2013/Published online: 3 January 2014

(c) Springer-Verlag Berlin Heidelberg and AWI 2014

\begin{abstract}
The relationship between body dry weight $(W)$ and shell length $(L)$ of blue mussels, Mytilus edulis, can be expressed by the condition index $\left(\mathrm{CI}=W / L^{3}\right)$ which varies from population to population and during the year. Here, we examine the influence of $\mathrm{CI}$ on the relationships between maximum filtration rate $\left(F, 1 \mathrm{~h}^{-1}\right), W(\mathrm{~g})$, and $L(\mathrm{~mm})$ as described by the equations: $F_{W}=a W^{b}$ and $F_{L}=c L^{d}$, respectively. This is done by using available and new experimental laboratory data on $M$. edulis obtained by members of the same research team using different methods and controlled diets of cultivated algal cells. For all data, it was found that $F_{W}=6.773 W^{0.678}$ and $F_{L}=0.00135 L^{2.088}$ which are very similar to equations for mussels with 'medium condition' $\left(\mathrm{CI}=4-6 \mathrm{mg} \mathrm{cm}{ }^{-3}\right): F_{W}=6.567 W^{0.681}$ and $F_{L}=0.00150 L^{2.051}$, with $b$ - and $d$-values within a few percent of the theoretically expected of $2 / 3$ and 2 , respectively. Further, based on the present data, we propose a correction factor expressed by the empirical relation $F_{W} /$ $F_{L}=0.3562 \mathrm{CI}^{2 / 3}$ which implies that $F_{W}$ tends to underestimate the actual filtration rate $\left(F_{L}\right)$ when $\mathrm{CI}<4.70$ and to overestimate the filtration rate when $\mathrm{CI}>4.70$.
\end{abstract}

Communicated by Franke.

H. U. Riisgård ( $ه)$

Marine Biological Research Centre, University of Southern

Denmark, Hindsholmvej 11, 5300 Kerteminde, Denmark

e-mail: hur@biology.sdu.dk

P. S. Larsen

DTU Mechanical Engineering, Fluid Mechanics, Technical

University of Denmark, Building 403, 2800 Kgs. Lyngby,

Denmark

D. Pleissner

School of Energy and Environment, City University of Hong

Kong, Tat Chee Avenue, Jiulong, Hong Kong
Keywords Mytilus edulis $\cdot$ Filtration rate $\cdot$ Condition index $\cdot$ Allometric equations

\section{Introduction}

Allometric equations for filtration rate of blue mussels, Mytilus edulis, are widely used in physiological, ecological, and modelling studies (e.g. Bayne 1976; Winter 1978; Jones et al. 1992; Riisgård 2001; Filgueira et al. 2008; Cranford et al. 2011; Larsen et al. 2013, Riisgård et al. 2013b), and therefore, it is important to understand and possibly refine these equations as more data become available. As to be expected, and also experimentally verified by Jones et al. (1992), Riisgård (2001) and Riisgård et al. (2011b), the filtration rate $(F)$ and gill area $(G)$ in $M$. edulis are near proportional to the square of the shell length $(L)$ of the mussel, i.e.: $F \approx L^{2}$ and $G \approx L^{2}$. Likewise, it may be expected that the body dry weight (W) may be near proportional to $L^{3}$, or reversed: $L$ is proportional to $W^{1 / 3}$, so that $F \approx\left(W^{1 / 3}\right)^{2}=W^{2 / 3}=W^{0.67}$. But it should be emphasized that the relationship between body dry weight and shell length as expressed by the condition index $\left(\mathrm{CI}=W / L^{3}\right)$ is not constant, but varies from population to population and during the year due to, e.g. spawning in spring, growth during summer, and starvation during winter. Thus, using the changes in the relationship between shell length and body dry weight in $M$. edulis reported by Dare (1976), Riisgård (2001) estimated that CI for 'standard' 55-mm-shell-length mussels was 6.6 in April, decreased due to spawning to 3.6 in June, followed by a summer recovery phase to become 7.8 in October. Because the relationship between gill area and shell length remains constant; it may be expected (see also Filgueira et al. 2008) that pronounced variations in CI 
influence the weight-specific filtration rate of mussels with same shell length. Therefore, disparity of values of powerlaw exponents reported by different authors may, apart from varying experimental conditions, reflect differences in the mussels' CI, see also Petersen et al. (2004).

Here, we examine the influence of condition index (CI) on the relationships between filtration rate $(F)$, dry body weight $(W)$, and shell length $(L)$ as described by the equations $F_{W}=a W^{b}$ and $F_{L}=c L^{d}$, respectively. This is done by using available and new experimental laboratory data on $M$. edulis measured over the years by various researchers in cooperation with the present first author using different methods that are believed to give accurate data for filtration rate of mussels stimulated by cultivated algal cells to filter at maximum speed.

\section{Materials and methods}

Earlier published data on maximum filtration rate $\left(F, 1 \mathrm{~h}^{-1}\right)$ and body dry weight $(W, \mathrm{~g})$ of blue mussels $M$. edulis (Riisgård and Møhlenberg 1979; Møhlenberg and Riisgård 1979) were supplemented with data for shell length ( $L$, $\mathrm{mm}$ ) from the original research protocols in order to estimate $F_{W}=a W^{b}, \quad F_{L}=c L^{d}$ and condition index $\mathrm{CI}=W(\mathrm{mg}) / L(\mathrm{~cm})^{3}$. Further, data from more recent publications (Riisgård et al. 2011b; Pleissner et al. 2013) as well as new experimental data have been used.

Filtration experiments

$F, W$, and CI were obtained on $M$. edulis collected in February 2013 near the Marine Biological Research Centre, Kerteminde (Denmark). Prior to experiments, the mussels were divided into five size groups ranging from 15 to $74 \mathrm{~mm}$, with five mussels in each group, and kept in separate aerated tanks $\left(11^{\circ} \mathrm{C}, 20 \mathrm{psu}\right)$. Filtration rates were measured as the volume of water cleared of suspended particles per unit of time (i.e. 'clearance method'). The reduction in the number of particles as a function of time was followed by taking water samples $(10 \mathrm{ml})$ at fixed time intervals from an aquarium containing a group of mussels with same shell length in well-mixed seawater, to which algal cells Rhodomonas salina were added, and measuring the particle concentration with an electronic particle counter (Elzone 5380). The algal cells had a diameter of about $6 \mu \mathrm{m}$ and were therefore retained by the gills of the mussels with $100 \%$ efficiency (Møhlenberg and Riisgård $1978)$. The filtration rate $(F)$ was determined from the exponential decrease in algal concentration as a function of time using the formula (Riisgård et al. 2011a, b): $F=V \times b / n$, where $V=$ water volume in aquarium, $n=$ number of mussels, and $b=$ slope of the regression line in a semi-ln plot for the reduction in algal concentration with time. A control experiment without mussels showed that sedimentation of algal cells was insignificant. After measurements of the filtration rate, the dry weight of soft parts of mussels ( $W, \mathrm{mg}$ ) was measured after drying it in an oven at $90{ }^{\circ} \mathrm{C}$ for $24 \mathrm{~h}$, and the shell lengths were measured with a caliper gauge.

\section{Comparison of feeding conditions}

A common feature for the filtration-rate data in the present study is the use of micro-algae monocultures that stimulate the mussels to filter at maximum rates. Thus, Phaeodactylum tricornutum, Dunaliella marina, Tetraselmis suesica were used by Riisgård and Møhlenberg (1979) and Møhlenberg and Riisgård (1979), whereas R. salina was used by Riisgård et al. (2011b), Pleissner et al. (2013), and in the present study as feed. In all experiments, the algal concentration was kept below the threshold concentration for pseudofaeces production and incipient saturation reduction of filtration activity (i.e. $<5 \mu \mathrm{g}$ chl $a \mathrm{l}^{-1}$, Clausen and Riisgård 1996; Riisgård et al. 2011a). Therefore, in spite of the various methods used, the measured filtration rates may be directly compared.

\section{Statistical analysis}

Investigation of effects of CI on $F$ after controlling for the effects of $W$ and $L$ was performed using analysis of covariance (ANCOVA) in SPSS version 12 after linearization of data. Analysis of equations for estimation of $F$ as a function of $W$ and $L$ was performed using one way analysis of variance (ANOVA) in SigmaPlot version 11.

\section{Results}

Table 1 shows all available data on $L, W, F$, and CI, along with the allometric power equations for $F$ versus $W$ and $L$ from five studies on $M$. edulis. In order to evaluate the importance of CI for the allometric equations, plots of all data (Fig. 1) as well as plots for mussels with 'low condition' ( $\mathrm{CI}<4)$, 'medium condition' $(\mathrm{CI}=4-6)$ and 'high condition' (CI $>6$ ) have been made (Fig. 2). The choice of limits 4 and 6 is arbitrary but guided by the range of observed values. The various allometric equations are shown in Table 2, Fig. 2. It is seen that the equations for all data: $F_{W}=6.773 W^{0.678}$ and $F_{L}=0.00135 L^{2.088}$ are very similar to the 'medium condition' equations: $F_{W}=6.567 W^{0.681}$ and $F_{L}=0.00150 L^{2.051}$, with $b$ - and $d$-values statistically similar (ANOVA, $p \sim 0.9$ ) to the theoretically expected of $2 / 3$ and 2 , respectively. However, 
Table 1 Mytilus edulis. Shell length $(L)$, body dry weight $(W)$, filtration rate $(F)$, gill area $(G)$, and condition index $(\mathrm{CI})$ of mussels measured in various studies by means of different methods. Estimated allometric power-law equations for $F$ versus $W$ and $L$, and $G$ versus $W$ and $L$ are shown

\begin{tabular}{|c|c|c|c|c|c|c|}
\hline $\begin{array}{l}L \\
(\mathrm{~mm})\end{array}$ & $\begin{array}{l}W \\
(\mathrm{~g})\end{array}$ & $\begin{array}{l}F \\
\left(1 \mathrm{~h}^{-1}\right)\end{array}$ & $\begin{array}{l}G \\
\left(\mathrm{~cm}^{2}\right)\end{array}$ & $\begin{array}{l}\mathrm{CI} \\
\left(\mathrm{mg} \mathrm{cm}^{-3}\right)\end{array}$ & Equations & $\begin{array}{l}\text { Reference/method/ } \\
\text { temperature/time } \\
\text { of mussel collection }\end{array}$ \\
\hline 10.8 & 0.006 & 0.18 & & 4.49 & $F_{W}=7.42 W^{0.72}$ & Riisgård and Møhlenberg (1979) \\
\hline 15.2 & 0.018 & 0.37 & & 5.21 & $F_{L}=0.0016 L^{2.00}$ & 'Photoaquarium method' \\
\hline 23.2 & 0.057 & 1.02 & & 4.56 & & $15{ }^{\circ} \mathrm{C}$ \\
\hline 33.4 & 0.132 & 2.16 & & 3.54 & & January 1978 \\
\hline 42.8 & 0.283 & 2.46 & & $\begin{array}{l}3.61 \\
4.28 \pm 0.70\end{array}$ & & \\
\hline 16.0 & 0.019 & 0.50 & & 4.64 & $F_{W}=7.29 W^{0.65}$ & Møhlenberg \& Riisgård (1979) \\
\hline 27.2 & 0.081 & 1.26 & & 4.03 & $F_{L}=0.0013 L^{2.12}$ & 'Suction method' \\
\hline 34.5 & 0.131 & 2.52 & & 3.19 & & $11-13^{\circ} \mathrm{C}$ \\
\hline 51.8 & 0.765 & 6.42 & & 5.50 & & February 1978 \\
\hline 61.5 & 1.345 & 7.80 & & $\begin{array}{l}5.78 \\
4.63 \pm 1.06\end{array}$ & & \\
\hline 16.0 & 0.03 & 0.30 & 3.5 & 7.32 & $F_{W}=6.38 W^{0.75}$ & Riisgård et al. $(2011 \mathrm{a}, \mathrm{b})$ \\
\hline 26.1 & 0.08 & 1.80 & 6.3 & 4.50 & $F_{L}=0.0008 L^{2.26}$ & 'Clearance method' \\
\hline 49.3 & 0.74 & 4.50 & 28.8 & 6.18 & $G=37.68 W^{0.69}$ & $12{ }^{\circ} \mathrm{C}$ \\
\hline 63.8 & 1.88 & 8.70 & 52.6 & 7.24 & $G=0.01 L^{2.05}$ & November 2009 \\
\hline 82.6 & 2.78 & 15.12 & 88.6 & $\begin{array}{l}4.93 \\
6.03 \pm 1.29\end{array}$ & & \\
\hline 15.3 & 0.014 & 0.50 & & 3.91 & $F_{W}=8.08 W^{0.65}$ & Pleissner et al. (2013) \\
\hline 30.4 & 0.219 & 2.60 & & 7.80 & $F_{L}=0.0019 L^{2.07}$ & 'FCA method' \\
\hline 31.8 & 0.279 & 2.90 & & 8.68 & & $12^{\circ} \mathrm{C}$ \\
\hline 45.1 & 0.212 & 4.30 & & $\begin{array}{l}2.31 \\
5.67 \pm 3.05\end{array}$ & & November 2011 \\
\hline 15.3 & 0.013 & 0.34 & & 3.49 & $F_{W}=5.39 W^{0.63}$ & Present study \\
\hline 20.7 & 0.037 & 0.54 & & 4.22 & $F_{L}=0.0016 L^{2.00}$ & 'Clearance method' \\
\hline 35.0 & 0.095 & 1.65 & & 2.21 & & $11^{\circ} \mathrm{C}$ \\
\hline 52.9 & 0.626 & 4.21 & & 4.23 & & February 2013 \\
\hline 73.6 & 1.600 & 6.48 & & $\begin{array}{l}4.01 \\
3.63 \pm 0.85\end{array}$ & & \\
\hline
\end{tabular}

the equations for mussels with 'low' and 'high condition' are divergent, and it is notable that the $a$-coefficient (equivalent to $F$ for a $1 \mathrm{~g}$ mussel) takes decreasing values $\left(9.180,6.567,6.380 \mathrm{l} \mathrm{h}^{-1}\right)$ for increasing values of condition index, from low to medium to high condition mussels, respectively, as does the $c$-coefficient (equivalent to $F$ for a 'theoretical' 1-mm mussel; 0.00189, 0.00150, $0.000681 \mathrm{~h}^{-1}$, Table 2; Fig. 2).

ANCOVA revealed that there is a significant effect of CI on $F$ after controlling for the effect of $W(\mathrm{CI}<4$ and $\mathrm{CI}>6: F_{(1,7)}=14.3, p<0.05 ; \mathrm{CI}<4$ and $\mathrm{CI}=4-6$ : $\left.F_{(1,16)}=4.9, p<0.05\right)$. No statistical impact of CI on $F$ was found between mussels with $\mathrm{CI}>6$ and $\mathrm{CI}=4-6$ : $F_{(1,12)}=3.7, p=0.08$, possibly because of the small amount of data for mussel with $\mathrm{CI}>6$. But contrarily to $W$, no impact of CI on $F$ was found after controlling for the effect of $L\left(\mathrm{CI}<4\right.$ and $\mathrm{CI}>6: F_{(1,7)}=0.3, p=0.59$;
$\mathrm{CI}>6$ and $\mathrm{CI}=4-6: F_{(1,16)}=1.2, p=0.29 ; \mathrm{CI}>6$ and $\left.\mathrm{CI}=4-6: F_{(1,12)}=0.3, p=0.59\right)$.

Noting that $b$ - and $d$-values for the 'medium condition' equations are close to the theoretically expected exponents (2/3 and 2), we propose an empirical $F-L-C I$ relation for all data of the form $F_{W} / F_{L}$, using the theoretical exponents, yielding $F_{W} / F_{L}=\left(a_{\mathrm{m}} / c_{\mathrm{m}}\right) \mathrm{Cl}^{2 / 3}$, where $a_{\mathrm{m}}$ and $c_{\mathrm{m}}$ are mean values fitted to the 'medium condition' data as follows. For each data point, we calculate $a=F / W^{2 / 3}$ and $c=F / L^{2}$, respectively, and average these values to obtain $a_{\mathrm{m}}=6.521 \mathrm{l} \mathrm{h}^{-1} \mathrm{~g}^{-2 / 3}$ and $c_{\mathrm{m}}=0.001831 \mathrm{~h}^{-1} \mathrm{~mm}^{-2}$, respectively, leading to the following 'model' equations:

$$
\begin{gathered}
F_{W}=6.521 W^{2 / 3} ; \quad F_{L}=0.00183 L^{2} ; \\
F_{W} / F_{L}=0.3562 C I^{2 / 3}
\end{gathered}
$$

where the units are $F\left(1 \mathrm{~h}^{-1}\right), W(\mathrm{~g}), L(\mathrm{~mm})$, and the constant $a_{\mathrm{m}} / c_{\mathrm{m}}=3,562 \mathrm{~mm}^{2} \mathrm{~g}^{-2 / 3}=0.3562 \mathrm{~cm}^{2} \mathrm{mg}^{-2 / 3}$. 

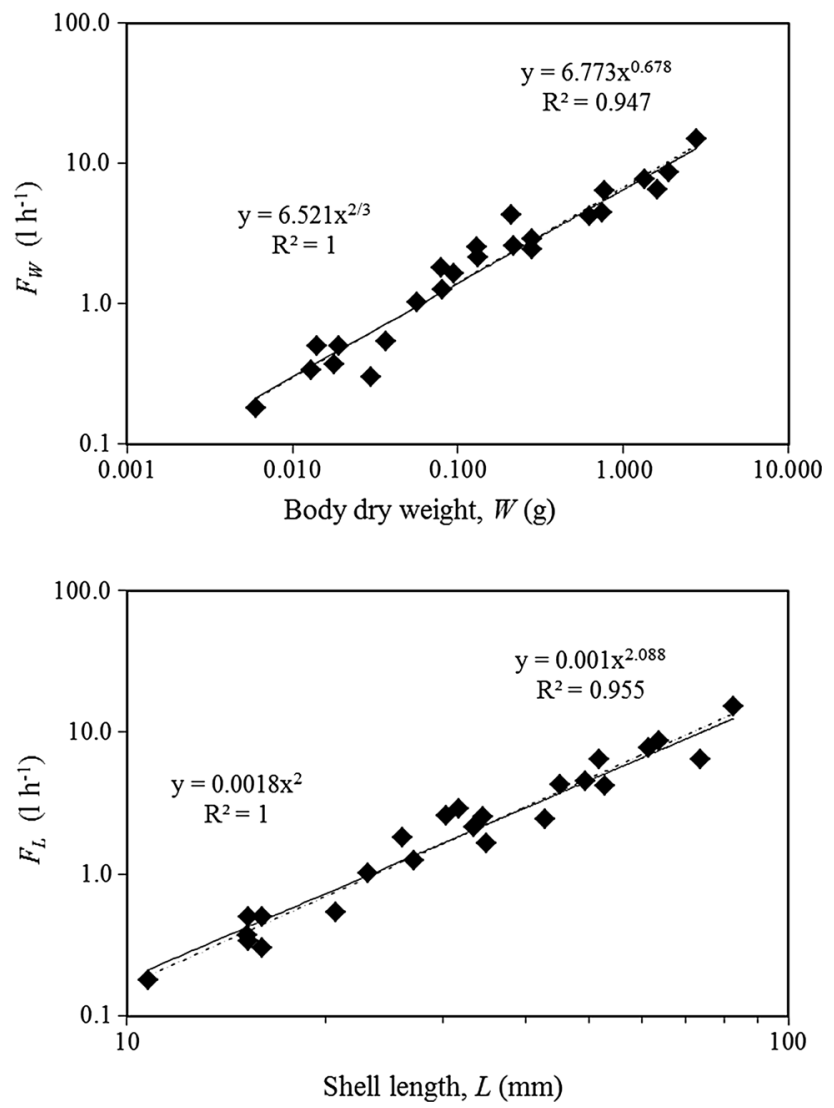

Fig. 1 Mytilus edulis. Filtration rate as a function of body dry weight $(W)$ and shell length $(L)$ based on all data in Table 1. Regression lines of data (dash) and of the allometric relations (solid) $F_{W}=a_{\mathrm{m}} W^{2 / 3}$ and $F_{L}=c_{\mathrm{m}} L^{2}$ based on $F_{W} / F_{L}=\left(a_{\mathrm{m}} / c_{\mathrm{m}}\right) \mathrm{CI}^{2 / 3}$ (see text) with corresponding equations shown

The first two relations of Eq. (1) are compared to all data in Fig. 1. The reciprocal of the third relation of Eq. (1), $\left(F_{L} /\right.$ $F_{W}$ ), is an estimate of a 'correction factor' to the estimated filtration rate based on $F_{W}$, and it appears that $F_{W}$ tends to underestimate the actual filtration rate $\left(F_{L}\right)$ when $\mathrm{CI}<\left(0.3562^{-3 / 2}=\right) 4.704$ and to overestimate the filtration rate when $\mathrm{CI}>4.704 \mathrm{mg} \mathrm{cm}^{-3}$ (Fig. 3).

\section{Discussion}

Although CI for all data sets varies between 2.21 and 8.68 (Table 1), the common equation for all data $F_{W}=6.76 W^{0.68}$ is near identical (ANOVA, $p=0.942$ ) to the 'medium condition' equation, possibly because lowand high-condition values tend to compensate each other. Due to seasonal changes in CI, the filtration rate (and gill size) is more closely related to shell length than to body weight, see also Filgueira et al. (2008) who have earlier pointed out the importance of condition index, although
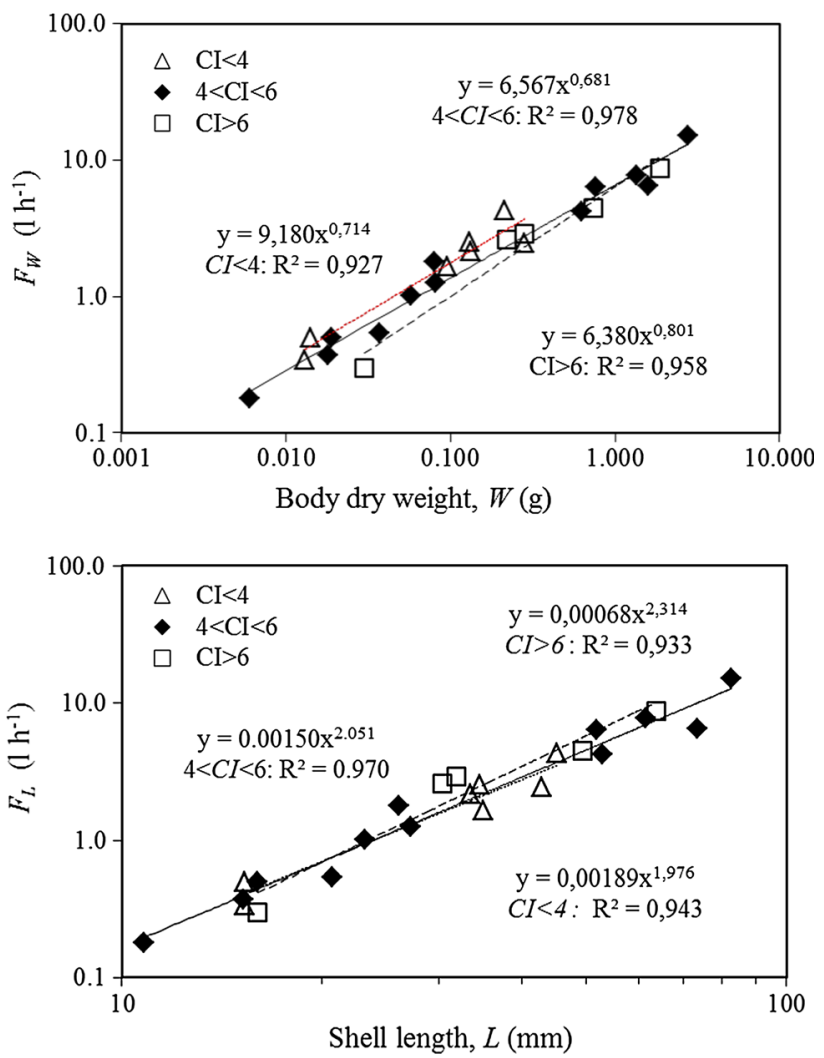

Fig. 2 Mytilus edulis. Filtration rate as a function of body dry weight $(W)$ and shell length $(L)$ of mussels with low $(\mathrm{CI}<4)$, high $(\mathrm{CI}>6)$, and medium $(\mathrm{CI}=4-6)$ condition index $(\mathrm{CI})$. Regression lines (dot, dash, solid for low, high, medium) and corresponding equations shown

Table 2 Mytilus edulis. Allometric power-law equations for filtration rate $\left(F, 1 \mathrm{~h}^{-1}\right)$ versus body dry weight $(W, \mathrm{~g})$ and shell length $(L$, $\mathrm{mm}$ ), based on data shown in Table 1 and Fig. 2

\begin{tabular}{lr}
\hline$F_{W}=6.91 \pm 1.05 W^{0.68 \pm 0.05}$ & Table 1 (all equations; \\
$F_{L}=0.0014 \pm 0.0004 L^{2.08 \pm 0.12}$ & mean \pm SD) \\
$F_{W}=6.773 W^{0.678}$ & Table 1 (all data; Fig. 1) \\
$F_{L}=0.00135 L^{2.088}$ & \\
$W=3.48 \times 10^{-6} L^{3.08}$ & $\mathrm{CI}<4$ 'low condition' (Fig. 2) \\
$F_{W}=9.180 W^{0.714}$ & \\
$F_{L}=0.00189 L^{1.976}$ & $\mathrm{CI}=4-6$ 'medium condition' \\
$F_{W}=6.567 W^{0.681}$ & (Fig. 2) \\
$F_{L}=0.00150 L^{2.051}$ & $\mathrm{CI}>6$ 'high condition' (Fig. 2) \\
$F_{W}=6.380 W^{0.801}$ & \\
$F_{L}=0.00068 L^{2.314}$ &
\end{tabular}

they used another definition, i.e. CI $=$ tissue dry weight/ shell dry weight $\times 100$.

The present $b$ - and $d$-values are within a few percent of the theoretical values of $2 / 3$ and 2 for $F$ versus $W$ and $L$, respectively, and we suggest that Eq. (1) for M. edulis, based on maximum filtration rates measured under 


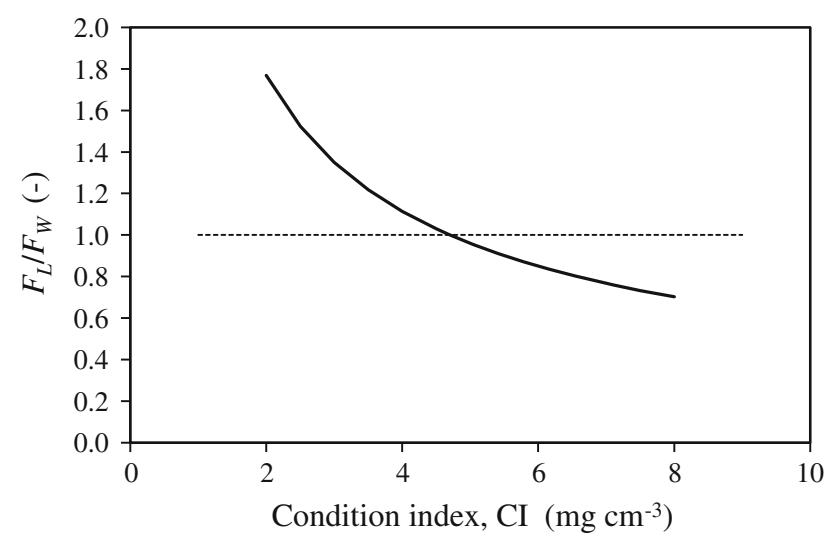

Fig. 3 Correction factor $\left[F_{L} / F_{W}=\left(0.3562 \mathrm{CI}^{2 / 3}\right)^{-1}\right]$ to filtration rate based on $F_{W}=a W^{b}$

controlled laboratory conditions using accurate methods, may be used as 'model' reference equations in future studies. From the allometric relation of Eq. (1) and its reciprocal shown in Fig. 3, it appears that use of $F_{W}=6.521 W^{2 / 3}$ (which is close to the 'medium condition', $F_{W}=6.567 W^{0.681}$ ) may underestimate the filtration rate of $M$. edulis estimated from the shell length by $42 \%$ at $\mathrm{CI}=2$ and overestimate the filtration rate by $46 \%$ for mussels with $\mathrm{CI}=8$. Recent laboratory and field growth experiments with mussels have revealed a tendency of CI to initially increase during the growth period (Riisgård et al. 2012a, b, 2013a, b), and this behaviour needs to be appropriately handled in modelling studies.

The present analyses of the parameters of the allometric relationship for $F$ versus $L$ show that most of the $b$-values are close to the theoretically expected value of 2 (Tables 1 , 2 ), which may be compared to the recent statement by Cranford et al. (2011, page 92 therein) that 'a more generally applicable $b$-value (for $F$ versus $L$ ) is $1.78 \pm 0.34$ $(n=10)$. Although there is considerable variability between studies, there appears to be a tendency for $b$-values to be less than the theoretical proportionality between gill area and shell length $\left(L^{2}\right)^{\prime}$. Nevertheless, this exponent is statistically similar to the theoretical value $b=2$. Finally, it is noted that the present data were obtained at three different temperatures, $11, \approx 12$, and $15{ }^{\circ} \mathrm{C}$. The sensitivity of filtration rate to change in temperature may be estimated to be $(1 / F) \mathrm{d} F / \mathrm{dt}=0.0251{ }^{\circ} \mathrm{C}^{-1}$, or about $2.5 \%{ }^{\circ} \mathrm{C}^{-1}$, according to the data of Kittner and Riisgård (2005, Fig. 3 therein, ranging from 10.3 to $20.3{ }^{\circ} \mathrm{C}$ ) implying variations from $-2.5 \%$ to $+7.5 \%$ about the level of the present data at $12{ }^{\circ} \mathrm{C}$. This variation is within the scatter of data which exceeds $20 \%$, but a plot of the three groups of data (not shown) indicates separate regression lines that confirm the predicted trend from 10 to $12{ }^{\circ} \mathrm{C}$ but not from 12 to $15{ }^{\circ} \mathrm{C}$.
It is clear from the present study that an additional relation is still required for models based on filtration and respiration being a function of dry weight of soft parts. This relation may involve the seasonally influenced growth period. But although changes in the mean dry weight of soft parts of mussels with a certain shell length collected from the same population generally vary with the annual cycle (Dare 1976), large individual variations in CI may be expected, dependent on living site (within or outside the tidal zone, on exposed stones, on suspended cultivation ropes, or within a dense mussel bed with strong intraspecific competition for food). Although based on controlled laboratory data, the present results may be considered as an allometric base line that would be useful for the analysis of field data that do not conform to the condition of maximum filtration rate.

Acknowledgments This work formed part of the MarBioShell project supported by the Danish Agency for Science, Technology and Innovation for the period, January 2008 to December 2012. Thanks to Ana Torrano Lozano for technical assistance and to an anonymous reviewer for many careful and constructive comments on the manuscript.

\section{References}

Bayne BL (1976) Marine mussels: their ecology and physiology. Cambridge University Press, Cambridge

Clausen I, Riisgård HU (1996) Growth, filtration and respiration in the mussel Mytilus edulis: no regulation of the filter-pump to nutritional needs. Mar Ecol Prog Ser 141:37-45

Cranford P, Ward JE, Shumway SE (2011) Bivalve filter feeding: variability and limits of the aquaculture biofilter. In: Shumway SE (ed) Shellfish aquaculture and the environment, chapter 4. Wiley, New York, pp 81-124

Dare PJ (1976) Settlement, growth and production of the mussel, Mytilus edulis L., in Morecambe Bay, England. Fish Investig Ser II 28(1): 1-25

Filgueira R, Labarta U, Fernández-Reiriz MJ (2008) Effect of condition index on allometric relationships of clearance rate in Mytilus galloprovincialis Lamarck, 1819. Rev Biol Mar Oceanogr 43:391-398

Jones HD, Richards OG, Southern TA (1992) Gill dimensions, water pumping rate and body size in the mussel Mytilus edulis L. J Exp Mar Biol Ecol 155:213-237

Kittner C, Riisgård HU (2005) Effect of temperature on filtration rate in the mussel Mytilus edulis-no evidence for temperature compensation. Mar Ecol Prog Ser 305:147-152

Larsen PS, Riisgård HU (2011) Validation of the flow-through (FTC) and steady-state (SS) methods for clearance rate measurements in bivalves. Biol Open, p 6. doi:10.1242/bio.201101

Larsen PS, Lundgreen K, Riisgård HU (2013) Bioenergetic model predictions of actual growth and allometric transitions during ontogeny of juvenile blue mussels Mytilus edulis. In: Nowak J, Kozlowski M (eds) Mussels: ecology, life habits and control. Nova Science, New York, pp 101-122

Møhlenberg F, Riisgård HU (1978) Efficiency of particle retention in 13 species of suspension feeding bivalves. Ophelia 17:239-246 
Møhlenberg F, Riisgård HU (1979) Filtration rate, using a new indirect technique, in thirteen species of suspension-feeding bivalves. Mar Biol 54:143-148

Petersen JK, Bougrier S, Small AC, Garen P, Robert S, Larsen JEN, Brummelhuis E (2004) Intercalibration of mussel Mytilus edulis clearance rate measurements. Mar Ecol Prog Ser 267:187-194

Pleissner D, Lundgreen K, Lüskow F, Riisgård HU (2013) Fluorometer controlled apparatus designed for long-duration algalfeeding experiments and environmental effect studies with mussels. J Mar Biol, p 12. doi:10.1155/2013/401961

Riisgård HU (2001) On measurements of filtration rate in bivalvesthe stony road to reliable data: review and interpretation. Mar Ecol Prog Ser 211:275-291

Riisgård HU, Egede PP, Saavedra IB (2011a) Feeding behaviour of mussels, Mytilus edulis, with a mini-review of current knowledge. J Mar Res, p 13. doi:10.1f155/2011/312459

Riisgård HU, Jørgensen BH, Lundgreen K, Storti F, Walther JH, Meyer KE, Larsen PS (2011b) The exhalant jet of mussels Mytilus edulis. Mar Ecol Prog Ser 437:147-164
Riisgård HU, Bøttiger L, Pleissner D (2012a) Effect of salinity on growth of mussels, Mytilus edulis, with special reference to Great Belt (Denmark). Open J Mar Sci 2:167-176

Riisgård HU, Lundgreen K, Larsen PS (2012b) Field data and growth model for mussels Mytilus edulis in Danish waters. Mar Biol Res 8:683-700

Riisgård HU, Pleissner D, Lundgreen K, Larsen PS (2013a) Growth of mussels Mytilus edulis at algal (Rhodomonas salina) concentrations below and above saturation levels for reduced filtration rate. Mar Biol Res 9:1005-1017

Riisgård HU, Lundgreen K, Larsen PS (2013b) Potential for production of 'mini-mussels' in Great Belt (Denmark) evaluated on basis of actual growth of young mussels Mytilus edulis. Aquac Int. doi:10.1007/s10499-013-9713-y

Winter JE (1978) A review on the knowledge of suspension-feeding in lamellibranchiate bivalves, with special reference to artificial aquaculture systems. Aquaculture 13:1-33 